\title{
Impact of monsoon rainfall on the total foodgrain yield over India
}

\author{
V PRASANNA \\ Climate Research Department, APEC Climate Center, Busan, South Korea. \\ e-mail: prasa_arnala@yahoo.com
}

The study focuses on understanding the variations of precipitation during summer monsoon season and its impact on Kharif and Rabi foodgrain yield over India. Total foodgrain yield over India during Kharif (summer) season is directly affected by variations in the summer monsoon precipitation (JuneSeptember). An increase (decrease) in rainfall is generally associated with an increase (decrease) in foodgrain yield. A similar correspondence during the Rabi (winter) foodgrain yield is not evident. The Rabi crop is not directly affected by variations in the post-monsoon precipitation (October-December) alone, also the summer season precipitation influences the Rabi crop through water and soil moisture availability over many parts of India. Though the reduction of rainfall activity during the entire summer monsoon season leads to reduction in crop yields, the occurrence of prolonged rainfall breaks also causes adverse effect on the crop growth resulting in reduced crop yields.

\section{Introduction}

Agriculture is the backbone of India's economy. Nearly $70 \%$ of the working population depends on agricultural activities for their livelihood. The majority of India's population depends on cereal and pulse production for sustenance. Rainfall occurring over India during summer monsoon season (the major rainy season generally starts in June and ends in September) significantly affects the agricultural production of the country by providing water for the two main crop growing seasons, Kharif (summer) and Rabi (winter). Variations in the monsoon rainfall affect the total foodgrain yield of India and also the country's economy, which largely depends on agriculture (Krishna Kumar et al. 2004). Roughly $65 \%$ of the population is rural and are dependent on agricultural related activities. India's growth in per capita food production during 1979-1992 was about $1.6 \%$ per annum - the highest in the world during this period. Agriculture contributes nearly $29 \%$ to the GDP. About $43 \%$ of India's geographical area is used for agriculture.

The Asian monsoon climate is significantly dominated by Indian summer monsoon rainfall (ISMR). Every year more than $80 \%$ of annual rainfall is received over only the Indian land grid points called all India summer monsoon rainfall index (hereafter AISMR) followed by Parthasarathy et al. (1995). Within a short span of 4 months starting from June through September (JJAS), AISMR plays a vibrant role on agriculture, economy, and living status of the people. It appears that year-to-year fluctuation is the most prominent variation on the interannual scale between the so called good

Keywords. All India rainfall; all India foodgrain production; active/break cycle; soil moisture; Kharif and Rabi crop yields; southwest and northeast monsoons. 
(poor) with above-average (deficient) rainfall strongly related with food productivity, even though modest decrease of $10 \%$ of long term mean rainfall leads to significant decrease in rice production over India (Swaminathan 1987; Abrol and Gadgil 1999). In addition, the interannual variability of AISMR shows larger impact on gross domestic product (GDP) and agricultural production of the country (Gadgil 1996; Webster et al. 1998).

Two vital monsoon systems prevail over the Indian subcontinent, namely, the summer monsoon (also known as southwest (SW) monsoon) and northeast (NE) monsoon (retreating monsoon). The SW monsoon has been studied widely compared to the NE monsoon. Post-monsoon season or simply the northeast monsoon rainfall (NEMR) season (OND) over south peninsular India and Sri Lanka is the major rainfall season (Dhar and Rakhecha 1983; Prasanna and Yasunari 2008), which helps agricultural production in this region (Kumar et al. 2007). NEMR received very less attention in terms of studies in interannual variability and its teleconnections compared to southwest monsoon rainfall (SWMR). While most parts of India receive nearly the entire portion of their annual rainfall during SWMR (Prasanna and Yasunari 2009), the southeast peninsular India falls under the rain shadow region during the summer season due to the presence of Western Ghats. This region therefore critically depends on the NEMR to supplement the inadequate precipitation during SWMR. Over the southeastern tip of the Indian peninsula and neighbouring Sri Lanka, nearly 50\% of the annual rainfall is received during the NEMR season (Prasanna and Yasunari 2008).

There were numerous studies carried out for understanding the crop-weather relationship over Indian region (e.g., Parthasarathy and Pant 1985; Parthasarathy et al. 1992; Selvaraju 2003; Krishna Kumar et al. 2004) and also on the dependence of the country's economy on agriculture (Kumar and Parikh 1998; Gadgil et al. 1999; Preethi and Revadekar 2012; Revadekar and Preethi 2012). These studies were mainly focused on the seasonal rainfall, but not on the day-to-day variation of rainfall on which the growth of the crop mainly depends. Even though crop requires water in all stages of its growth, the occurrence of extreme dry or wet rain spell events can cause damage to the crop and hence its yield (Preethi and Revadekar 2012; Revadekar and Preethi 2012). A reduction in rainfall can cause drought while an increase in the intensity of rainfall and frequent occurrence of heavy rainfall days can lead to flood, but both the drought and flood can cause damage to crop. This makes it important to study the impact of dry and wet rainfall spells on the foodgrain yield.

\section{Data and method of analysis}

\subsection{Data sources}

\subsubsection{Rainfall data}

The AISMR index anomaly calculated from the monthly mean subdivisional rainfall dataset available from IITM for the period of 1966-2010 are used in this study, the index is an area weighted monthly rainfall series for India as a whole (Parthasarathy et al. 1995) prepared from data of 306 rain-gauge stations provided by the India Meteorological Department (IMD) uniformly distributed over the country (also used as observed rainfall index data) for the period 1966-2010, available from website of Indian Institute of Tropical Meteorology (IITM), [http://www.tropmet.res. in/].

Apart from rainfall index, high-resolution $\left(1^{\circ}\right.$ latitude $\times 1^{\circ}$ longitude) gridded daily rainfall dataset for Indian region for the period 1966-2007 (Rajeevan et al. 2005, 2006) has also been used in this study; this data has been extensively used for many research studies (Krishnamurthy and Shukla 2008; Prasanna and Annamalai 2012; Preethi and Revadekar 2012; Revadekar and Preethi 2012). The dataset is based on rainfall data of 1803 stations each with at least $90 \%$ data availability and is available for a period of 57 years, from 1951 to 2007 (e.g., Rajeevan et al. 2006).

\subsubsection{Soil moisture data}

This study also uses CPC soil moisture data to bring out the role of soil moisture impacts on food grain yield and its variance (Fan and van den Dool 2004).

The soil moisture data used in this study is a $0.5 * 0.5$ monthly global soil moisture dataset produced using a land model (one-layer 'bucket' water balance model). Input fields for the land model are Climate Prediction Center monthly global precipitation over land, which uses over 17,000 gauges worldwide, and monthly global temperature from global reanalysis. Since there are no direct soil moisture observations on the large continental area, water balance method is a good way to achieve soil moisture data on a continental scale.

\subsubsection{Kharif foodgrain yield}

Kharif foodgrain yield over India for agricultural years 1966-1967 to 2009-2010 (1st June to 31st May; a complete financial year) have been collected from the publication, 'Agricultural Statistics at a 
Glance 2006', compiled by the Directorate of Economics and Statistics of the Department of Agriculture Cooperation (DES 2010) which is a mirror of progress in the agriculture sector at all-India level as well as across the states. The foodgrain yield exhibits an increasing trend since early 70's, mainly due to expanded use of highyielding varieties of crops, changing cropping patterns and agricultural practices as mentioned by Krishna Kumar et al. (2004). Hence, the time series of aggregate Kharif foodgrain yield and the Rabi foodgrain yield have been detrended to see the natural interannual variability in the yield and are used as an index of foodgrain yield.

\subsection{Method of analysis}

Impacts of precipitation during summer monsoon on Kharif and Rabi foodgrain yield over India have been studied by computing correlation between seasonal time series of the indices and the detrended time series of all-India aggregate
Kharif foodgrain yield using Karl Pearson correlation method. The statistical significance of correlation coefficients is tested at $5 \%$ and $1 \%$ level of significance. Further, the association between all-India daily anomalies during the seasonal rainfall (JJAS/OND) and the aggregate Kharif foodgrain yield has been studied by computing composite anomalies between the detrended time series of all-India Kharif foodgrain yield and all-India daily anomalies for (JJAS/OND) seasonal time series of indices of precipitation. Analysis has also been carried out for some selected Kharif and Rabi seasons to understand how the relation varies from summer to winter crop.

The detrended data is done by using linear trend method similar to the studies by Preethi and Revadekar (2012) and Revadekar and Preethi (2012). Earlier study by Krishna Kumar et al. (2004) used backward differences (Box and Jenkins 1976) for interannual studies. Detrending by backward difference method reduces piece-wise linear trends in the data, which effectively removes the trend in the data. Other simple way of detrending
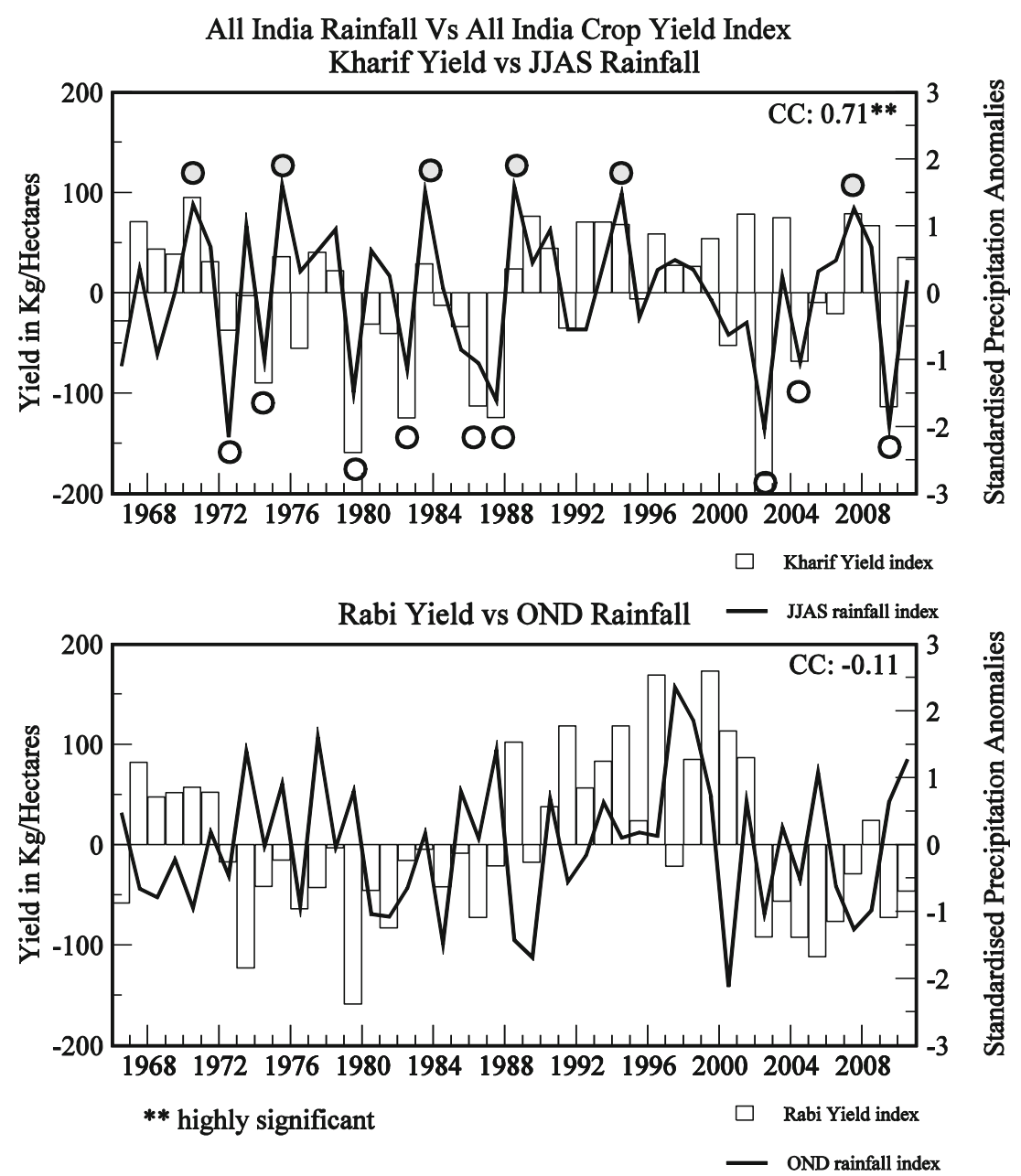

Figure 1. All India rainfall index vs. all-India crop yield index. (a) SW monsoon and (b) NE monsoon. 
the timeseries is by removing the trend using the linear trend analysis as employed in the papers by Preethi and Revadekar (2012) and Revadekar and Preethi (2012).

\subsection{All-India indices}

To obtain a representative value for the country as a whole, all-India time series of indices of precipitation are constructed by area-averaging the indices at all land-point grids. All values of monthly and seasonal all-India indices of precipitation are obtained by considering a 45-year period from 1966 to 2010 . To understand the variability in frequency of rainfall, mean and standard deviation of the all India indices are calculated and standardized anomalies are constructed for the 45-year period and are presented in figure 1. Daily values of allIndia indices are also constructed to create composites for active/break or wet/dry monsoon months, June to September, but the variability of rainfall correlate well only with foodgrain yield during the months of JJAS compared to OND season.
Composite monthly and seasonal count of rainy days corresponds well with the composites of wet/dry and vice versa. Similar results are reported for winter monsoon season (OND) as well, but the variability of rainfall does not correlate well with OND crop yields than that during summer monsoon season (JJAS).

\subsection{Variation in foodgrain production over India}

Though the foodgrain yield may have attained the highest possible growth, the decrease in area under crop during the Kharif season is a worrisome trend (figure 2). Much of the increase is likely due to development of crop varieties, fertilizers, expanded use of high-yielding varieties, and changing cropping patterns and agricultural practices as mentioned by Krishna Kumar et al. (2004). Therefore, the time series of Kharif yield is linearly detrended to obtain its year-to-year natural variability (figure 2). The figure indicates that interannual variability of summer monsoon rainfall may be the primary factor that affects the yield in India.
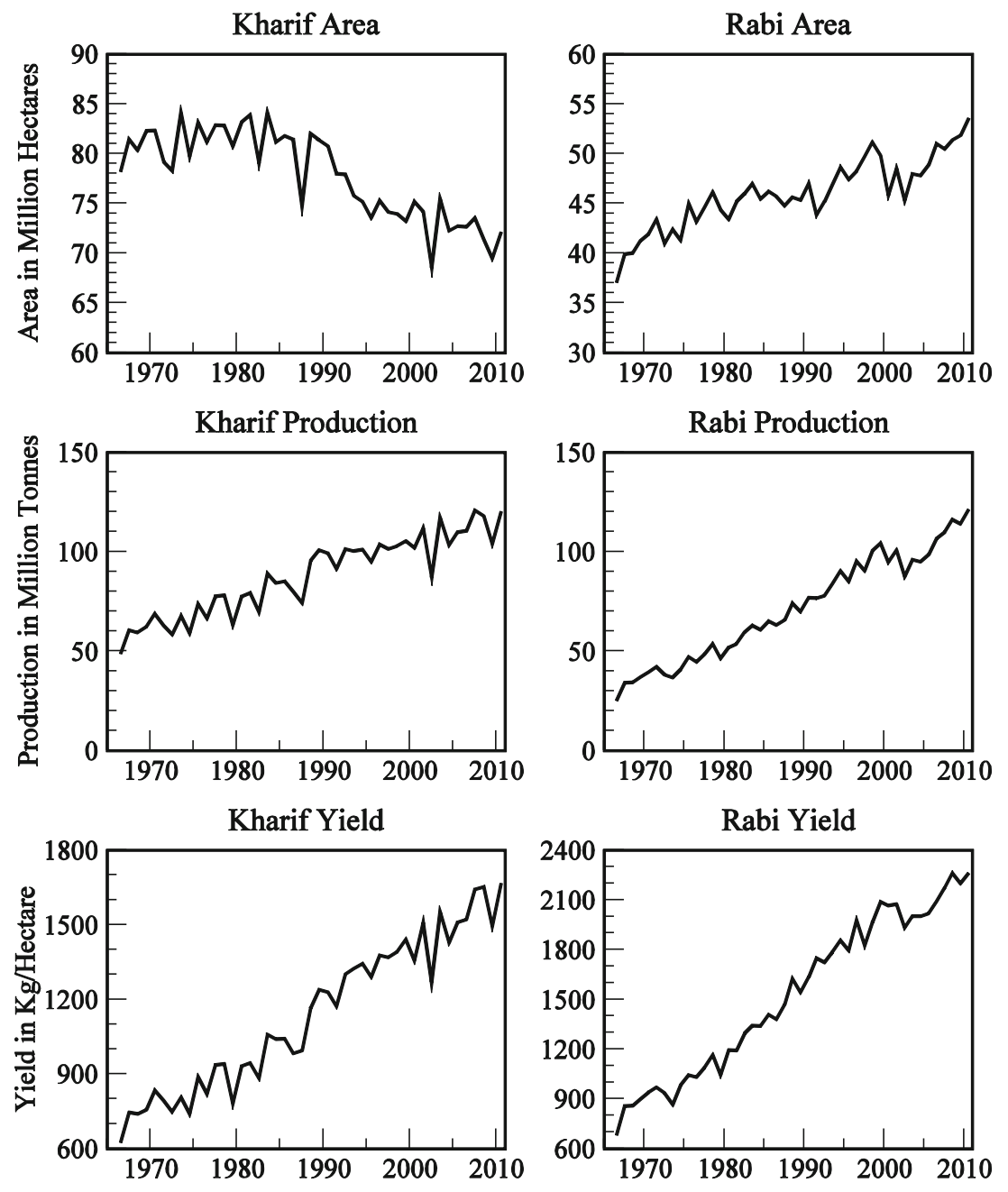

Figure 2. Normal area, production and yield statistics of the total food grains over India. 

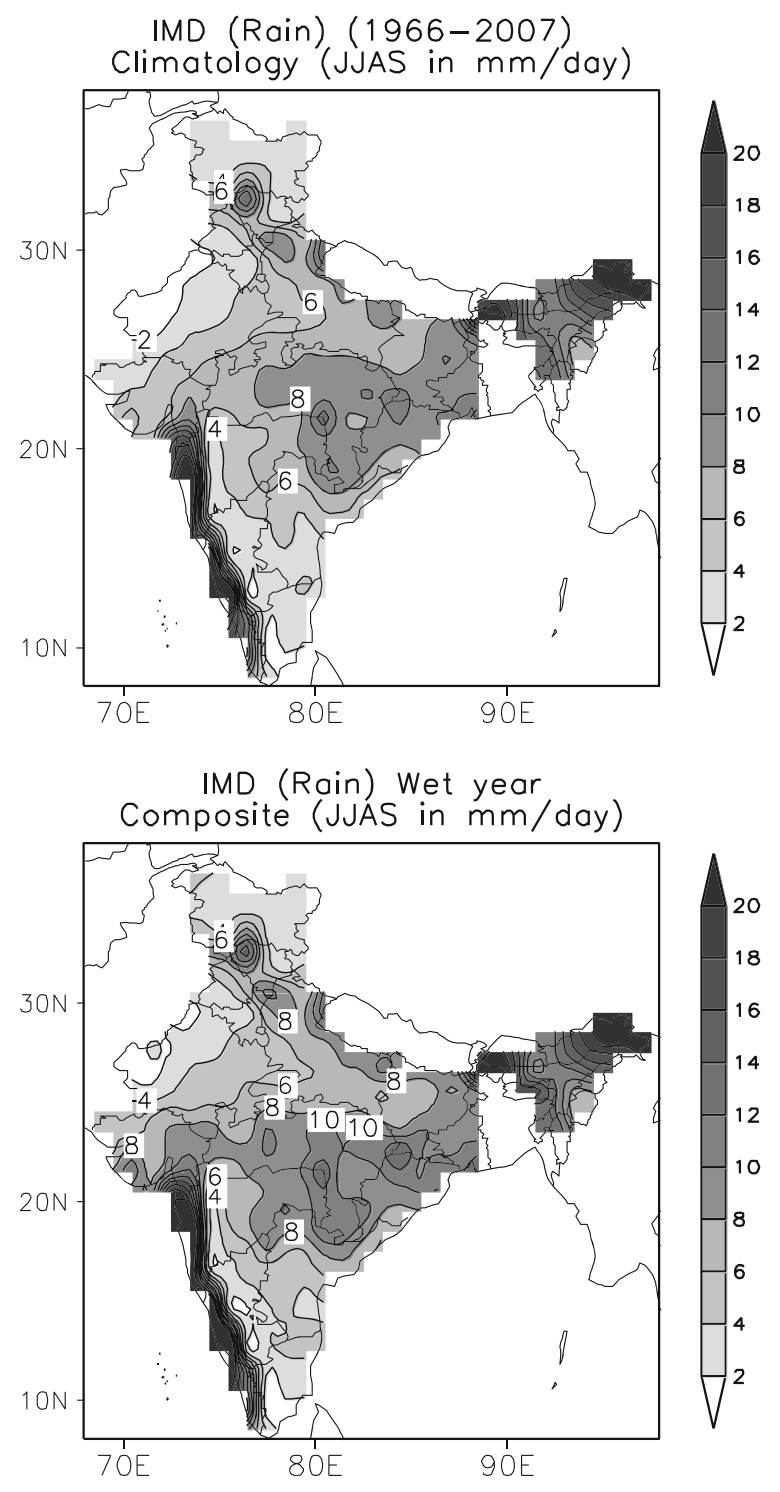

IMD (Rain) Wet year percent departure (JJAS in \% dep)
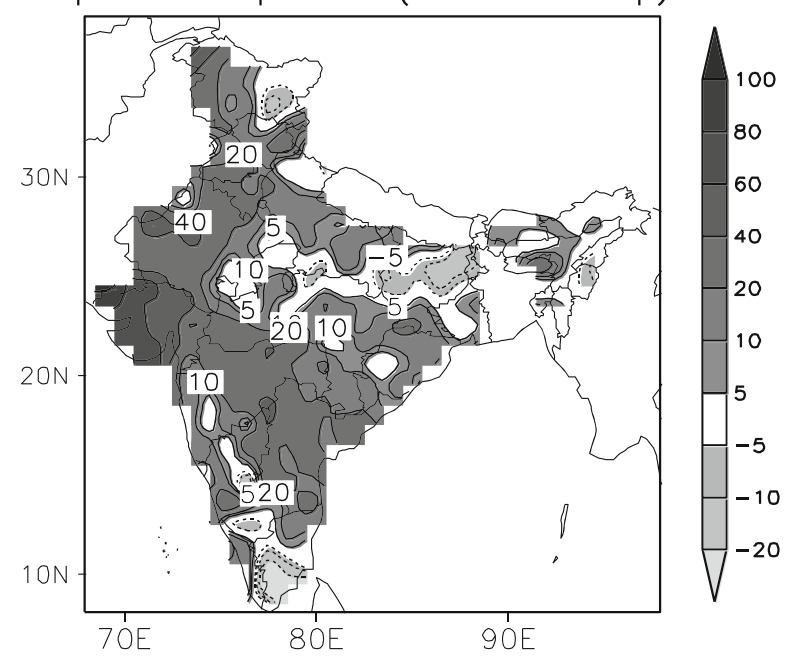

Figure 3. Precipitation anomaly composite for wet years of JJAS season. (a) Climatology, (b) composite and (c) percentage departure.
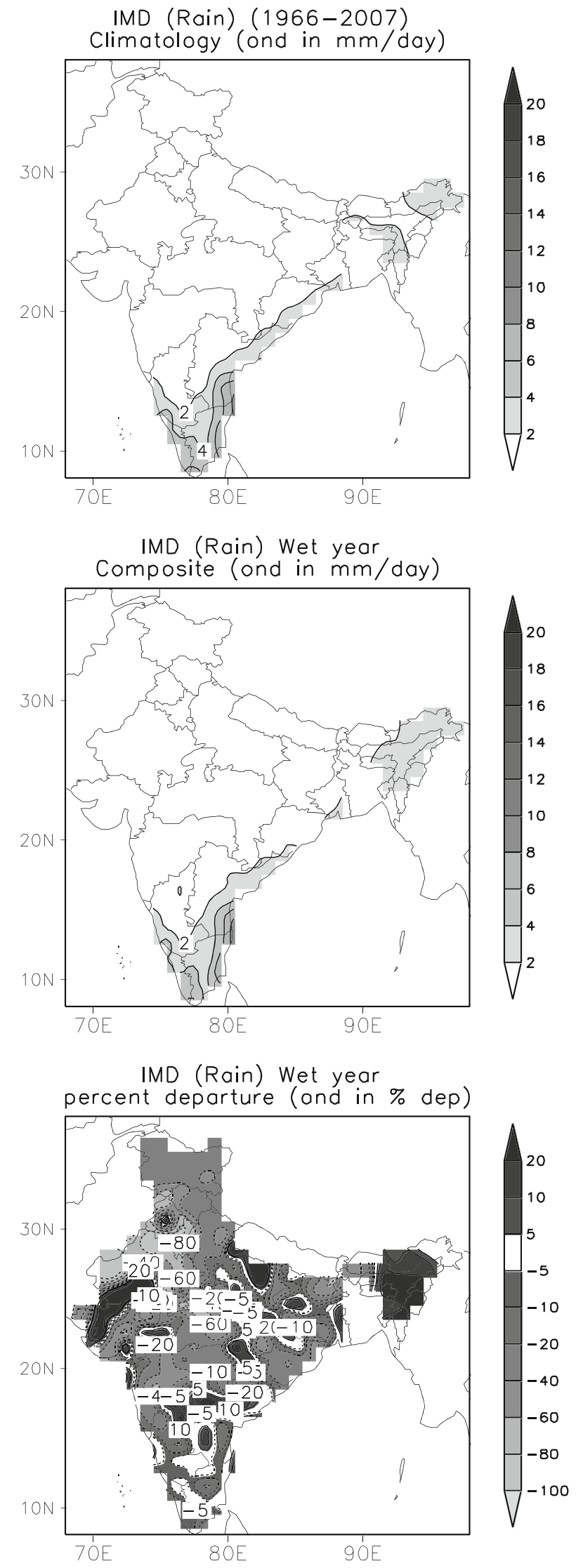

Figure 4. Precipitation anomaly composite for wet years of OND season. (a) Climatology, (b) composite and (c) percentage departure. 

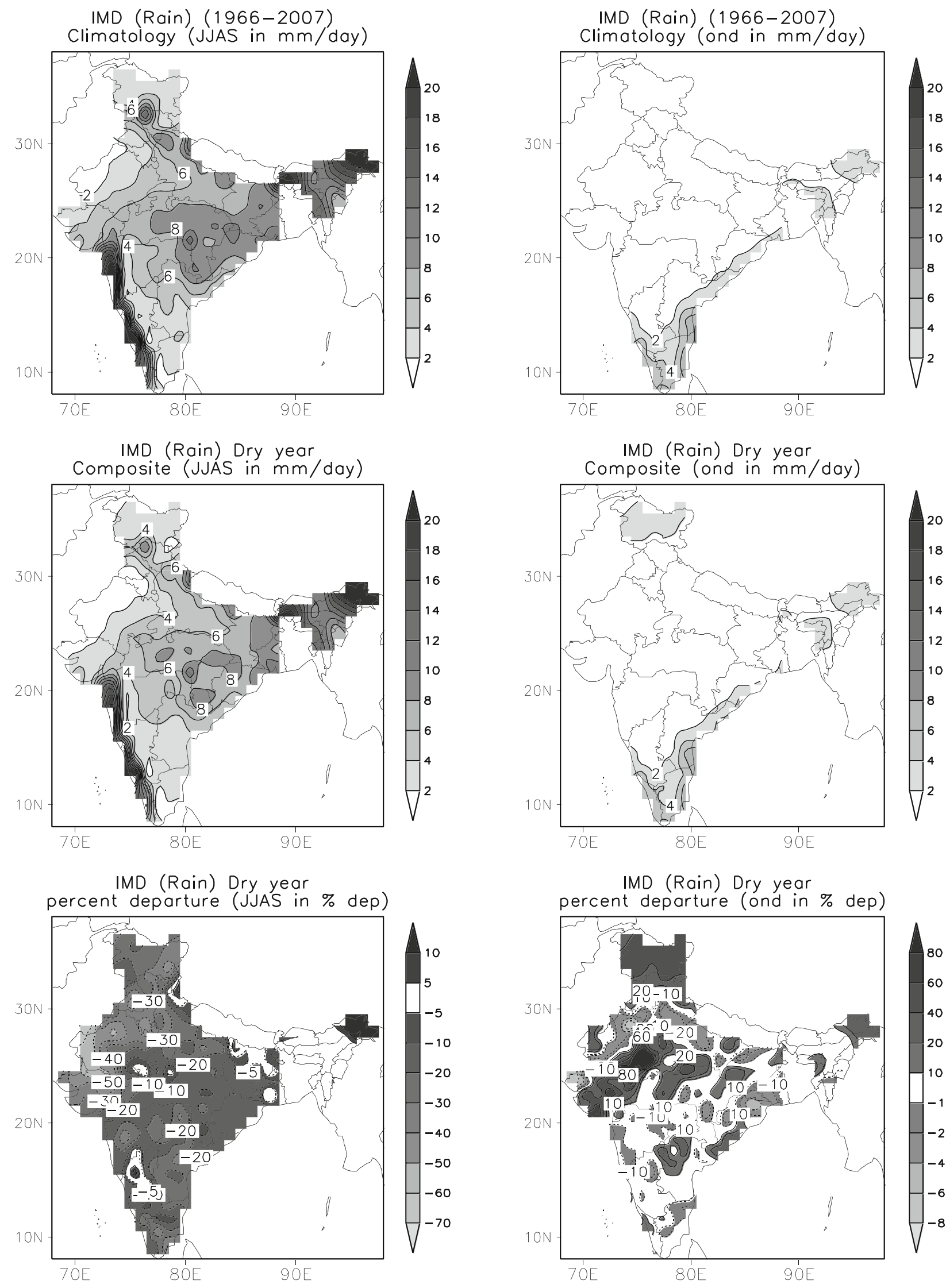

Figure 5. Precipitation anomaly composite for dry years of JJAS season. (a) Climatology, (b) composite and (c) percentage departure.

Figure 6. Precipitation anomaly composite for dry years of OND season. (a) Climatology, (b) composite and (c) percentage departure.

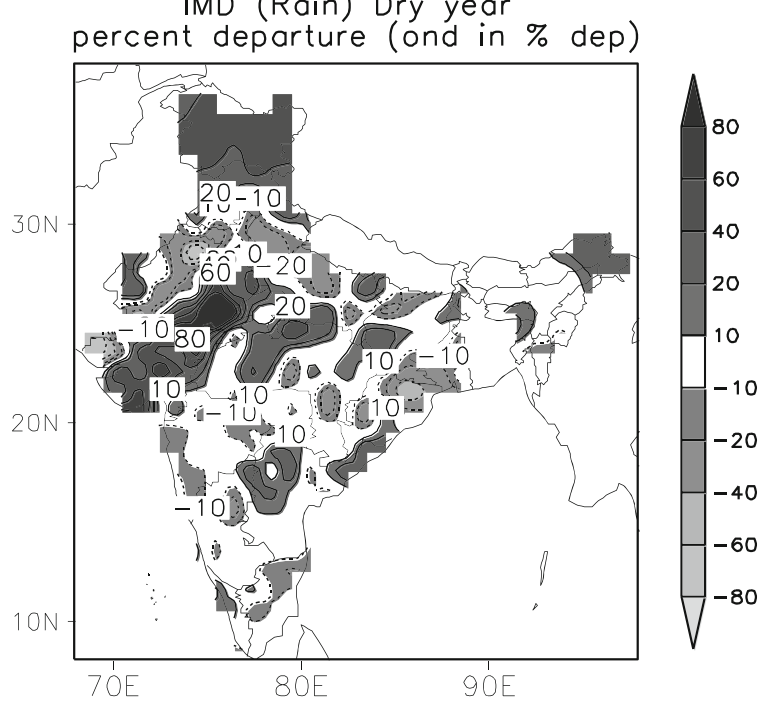


Extreme weather conditions such as floods, droughts seem to have an impact on the fluctuations in yield. Substantial decrease in yield is associated with drought years and the increase in yield is associated with excess and normal years. The figure clearly shows that negative impacts of deficit rainfall are larger than the positive impact of good rainfall on foodgrain yield over India. Similar features were also noted by Gadgil and Rupa Kumar (2006).

\section{Rainfall signal in the Indian foodgrain yield}

The summer or 'Kharif' growing season (JuneSeptember) coincides with the southwest monsoon. Depending on crop duration, Kharif crops can be harvested during the autumn (October-November) or winter (December-February) months. The southwest monsoon is critical to the Kharif crop, which accounts for more than $50 \%$ of the food grain production and more than $65 \%$ of the oil seeds production in the country (Krishna Kumar et al. 2004). Year-to-year fluctuations in summer monsoon rainfall over India have a strong impact on the variability of Kharif foodgrain production (Parthasarathy et al. 1988, 1992).

The 'Rabi' growing season starts after the summer monsoon, and continues through the following spring or early summer. Rainfall occurring at the end of the monsoon season provides stored soil moisture and sometimes irrigation water for the rabi crop, which is sown in the post-monsoon

(a)

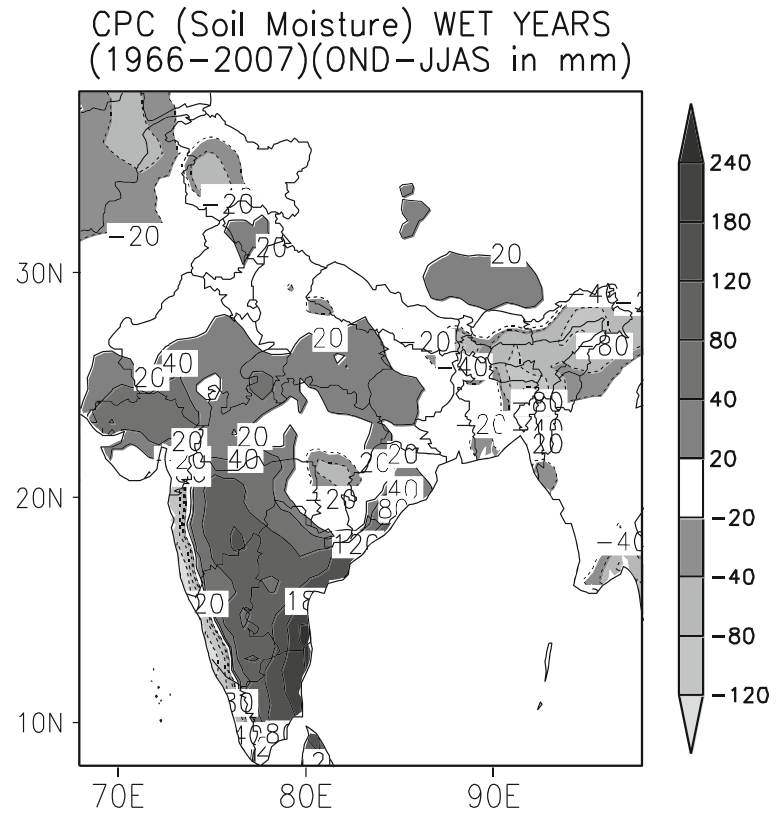

season (October-November). The summer monsoon therefore is responsible for both Kharif and Rabi crop production over India. The NE (winter) monsoon contributes substantial rainfall in much of Tamil Nadu and eastern Andhra Pradesh, permitting rainfed crop production during the Rabi season.

Rainfall during the end of summer monsoon season provides soil moisture for Rabi crops, while Kharif crops are directly affected by day-to-day variations in summer monsoon rainfall (Revadekar and Preethi 2012). Thus the rainfall in summer monsoon season is important for both Kharif and Rabi crops. Kharif is the main crop growing season over India which coincides with summer monsoon season. During the summer monsoon season, the country receives plenty of rainfall which is critical for the Kharif crops, which accounts for more than $50 \%$ of the foodgrain production in the country (Krishna Kumar et al. 2004). Kharif crop growth is directly affected by day-to-day variations in summer monsoon precipitation.

Year-to-year fluctuations in summer monsoon rainfall over India have a strong impact on the variability of aggregate Kharif foodgrain production (Parthasarathy et al. 1992; Gadgil 1996; Webster et al. 1998). Years with deficient and excess monsoon rainfall are associated with low and high production of foodgrain, respectively. But, the negative impact of deficit rainfall is larger than the positive impact of good rainfall (Gadgil and Rupa Kumar 2006). The fact that reduction of rainfall or occurrence of heavy rainfall activity may cause adverse effect on the foodgrain yield, point towards

(b)

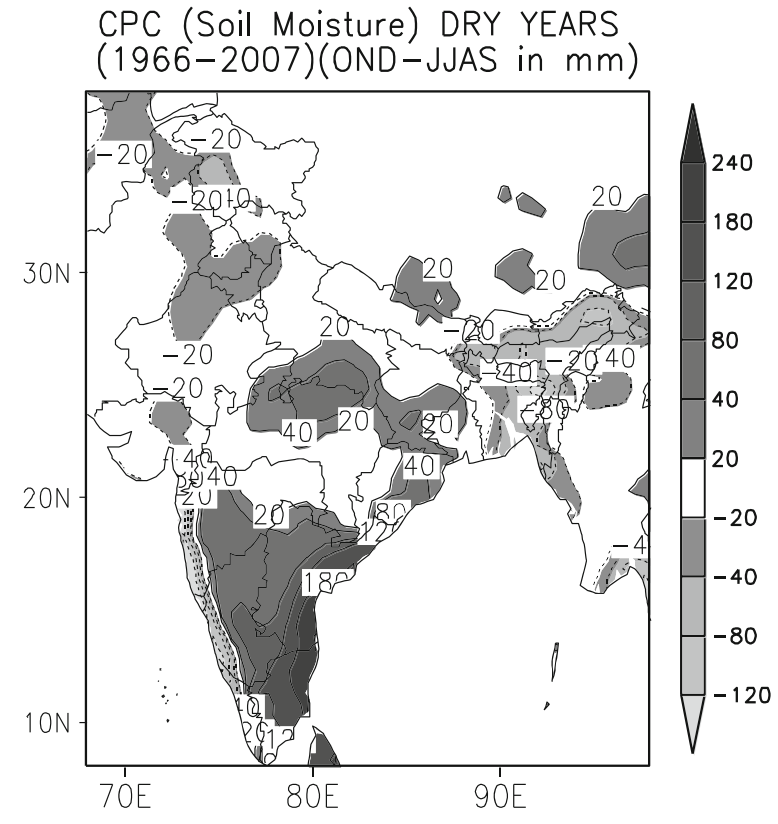

Figure 7. Difference in soil moisture composites between post-monsoon and summer monsoon anomaly in percentage departure for wet and dry years. (a) Wet years and (b) dry years. 
the existence of a nonlinear relationship between precipitation and better foodgrain yield. Therefore a detailed analysis has been carried out in this section to see the relationship between seasonal indices of precipitation and Kharif foodgrain yield over India.
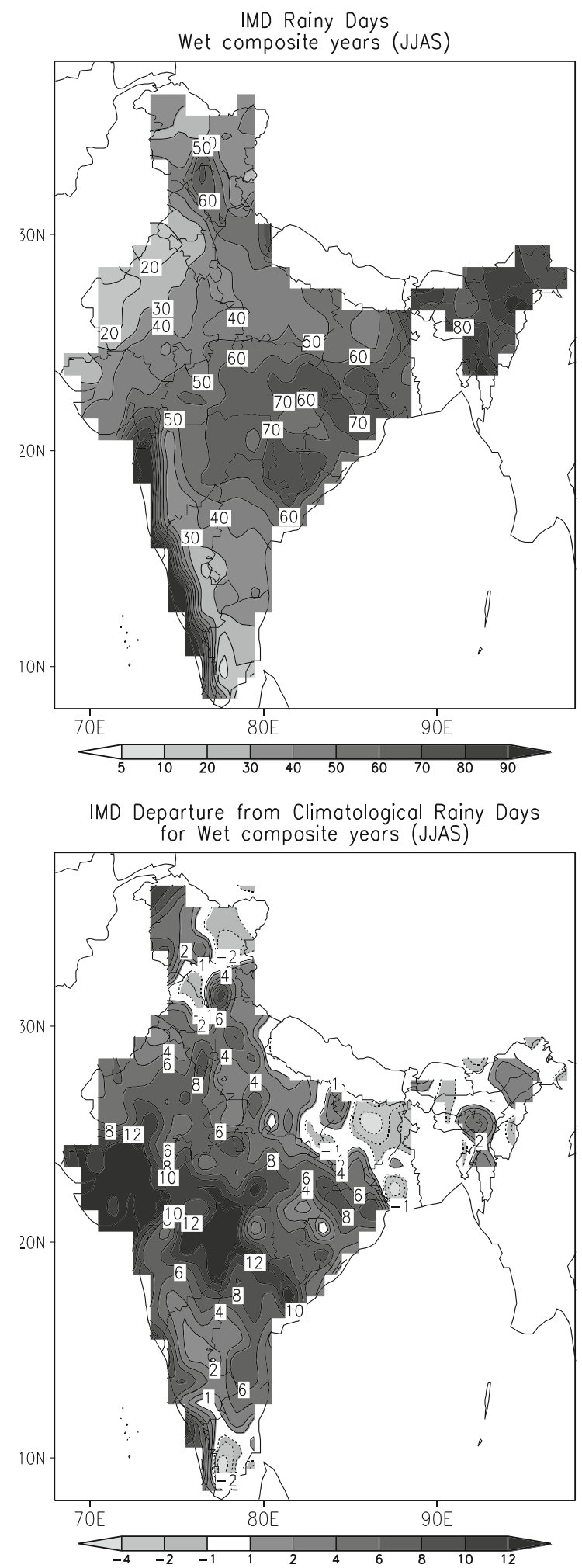

\subsection{Rainfall features over the Indian region}

Most parts of India receives maximum amount of annual rainfall from the SWMR (JJAS) compared to NEMR (OND) (figure not shown). The seasonal precipitation during SWMR covers more than $80 \%$
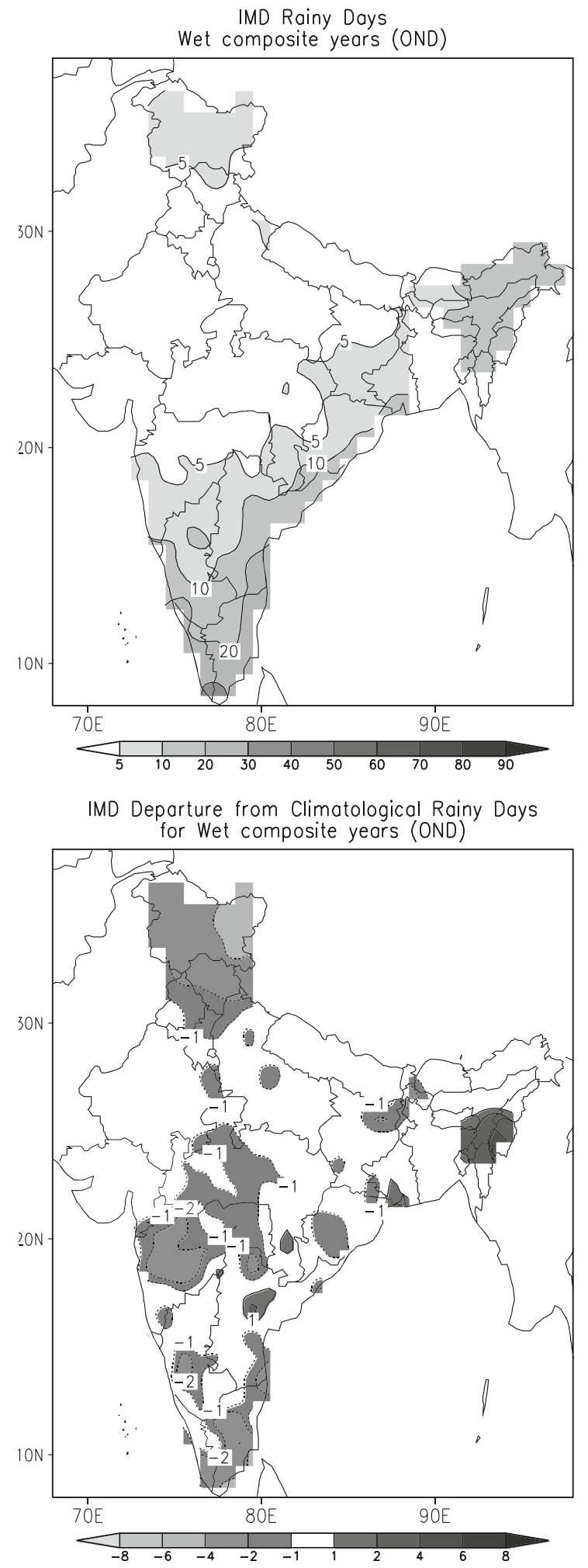

Figure 8. Composite mean and difference in the number of rainy days between JJAS and OND seasons during wet years. 

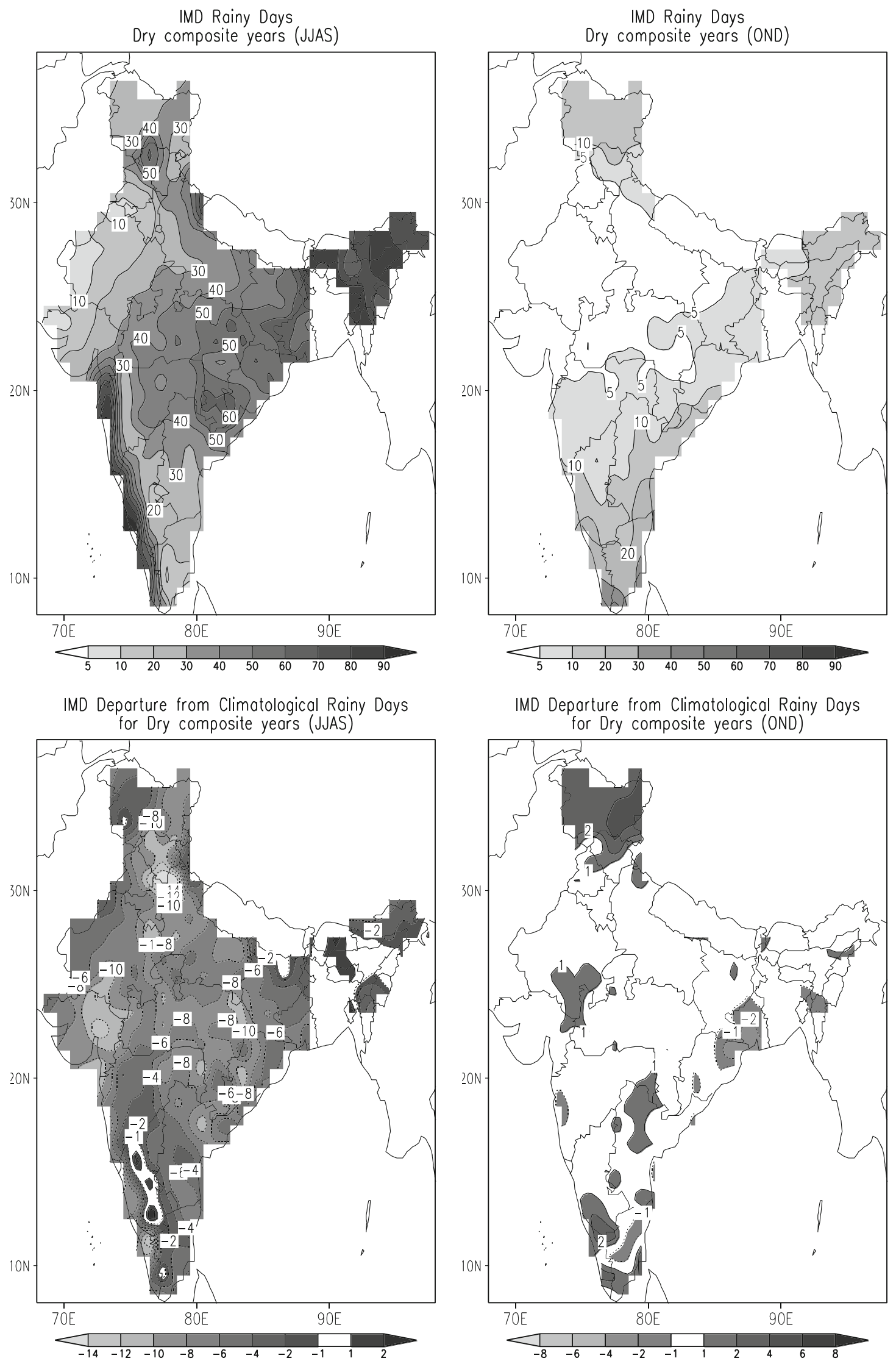

Figure 9. Composite mean and difference in the number of rainy days between JJAS and OND seasons during dry years. 
of the country while only $20 \%$ of the country is covered by the NEMR (Parthasarathy et al. 1995; Pant and Rupakumar 1997; Prasanna and Yasunari 2008, 2009). The percentage contribution of seasonal rainfall to the total annual precipitation (figure not shown) clearly indicated that the country is well dominated by the SWMR season, while only southeastern peninsular India is dominated by NEMR.

\subsection{Composite analysis of precipitation and soil moisture}

Composite analysis is done for wet and dry years by selecting years based on the data from figure 1 . The six wet years are 1970, 1975, 1983, 1988, 1994 and 2007, respectively (grey filled circles in figure 1). The eight dry years are 1972, 1974, 1979, 1982, 1986, 1987, 2002, and 2004, respectively (open circles in figure 1).

Composite analysis for high yield (wet) and low yield (dry) years has been analyzed in detail. The composite analysis clearly brings out the importance of summer monsoon (JJAS) over the northeast monsoon season (OND) for wet and dry years in the spatial extend of dryness or wetness. During wet years, most parts of India especially over the north, northwest, central, and peninsular India receive above normal rainfall during wet years ranging from +10 to $+100 \%$ departure (figure 3 ), while during the same years the NEMR season receives less seasonal rainfall and departures ranging from -10 to $-90 \%$ over central and northern parts of India (figure 4).

Similarly, as per composite analysis during dry years, most parts of India especially over the northwest, central, and peninsular India receive below normal rainfall during dry years ranging from -10 to $-70 \%$ departure (figure 5 ), while during the same years the NEMR season receives more seasonal rainfall and departures ranging from +10 to $+100 \%$ over central and northern parts of India (figure 6).

Further analyzing the soil moisture anomaly difference between post-monsoon season (OND) and monsoon season (JJAS) for wet years and dry years from CPC soil moisture data (figure 7), the signals are clearly visible over the central, north and northwest Indian regions. The positive soil moisture anomalies in the range of +40 to $+80 \%$ departure in wet years and the negative

Daily Mean Precipitation over India (1966-2007)

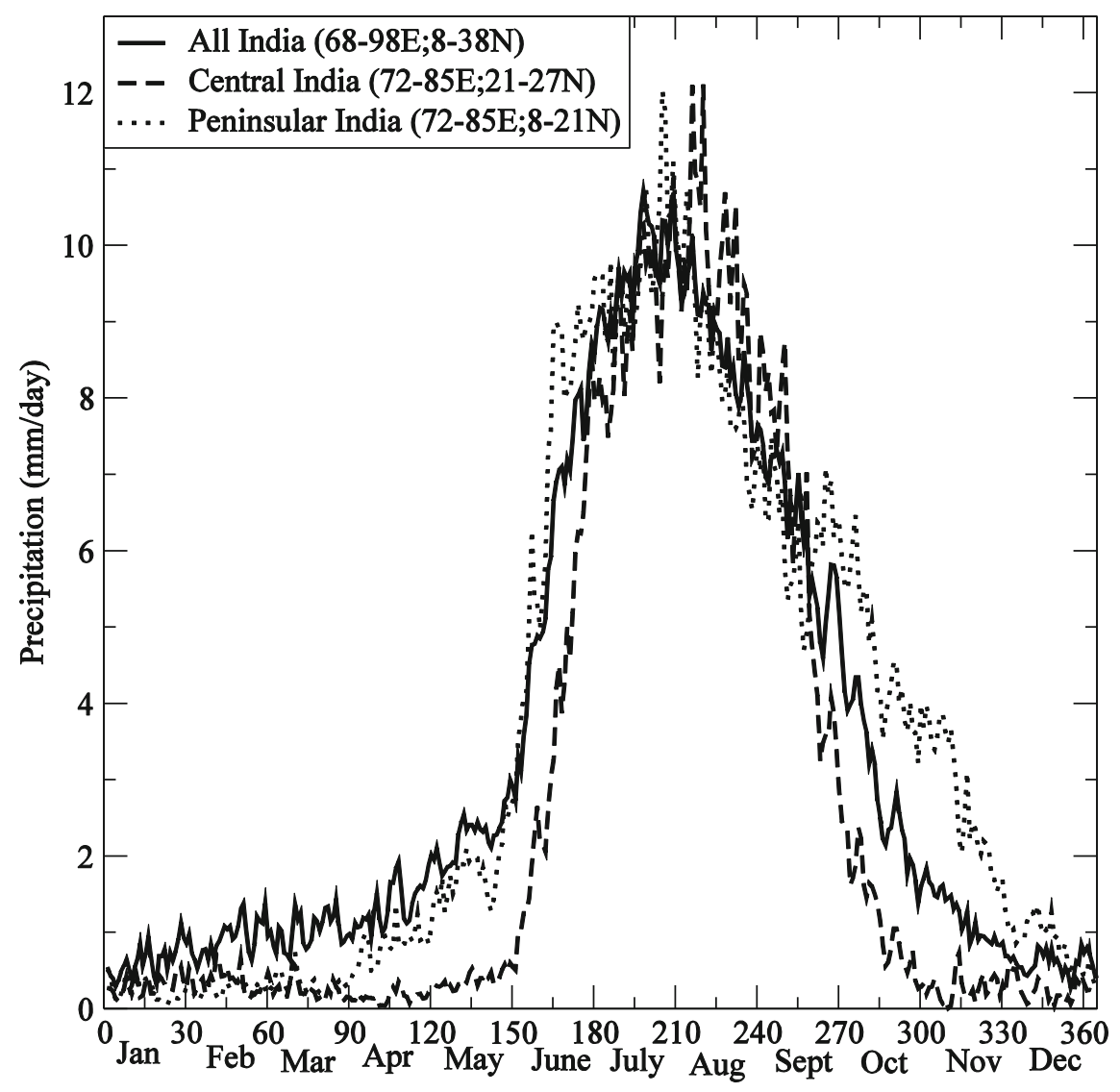

Figure 10. Daily climatological evolution of monsoons over different domains. 
soil moisture anomalies in the range of -40 to $-80 \%$ departure in dry years are evident from the figure 7.

A field study by Santosh et al. (2011) showed that the yield, economics, and available soil moisture influences different Rabi crops under rainfed conditions by soil types over Bijapur, Karnataka. There are not many studies over India which shows the soil moisture impact on agricultural yield on all-India scale, but the study that they have carried out is a field experiment during Rabi 2007-2008 at the Regional Agricultural Research Station, Bijapur and they have found that the influence of soil moisture and soil types on yield and economics of different Rabi crops are significant. The experiment was laid out in split plot design with four replications comprising two main plot treatments as soil types (medium black and deep black) and five subplot treatments as crops (sorghum, sunflower, chickpea, coriander and safflower). They found significantly higher total moisture stored (452.82 mm/0.9 $\mathrm{m}$ depth) during the cropping period and consumptive use of water (219.52 mm/0.9 m depth) was noticed in sunflower crop, while significantly higher water use efficiency $(8.27 \mathrm{~kg} / \mathrm{ha}-\mathrm{mm})$ was noticed in sorghum crop in their study. Their study also reiterates that the availability of water and stored soil moisture will impact the yield in the Rabi season.

Since soil moisture is not measured on grid scale, it is not possible to discuss in detail the impact of soil moisture on each crop. The only encouraging result we got in this study is that the soil moisture anomalies coincide well with the precipitation anomalies in the previous season. The impact of soil moisture availability will depend on soil types and crops phenology. Therefore, it is only possible to infer the large scale impact of soil moisture for a season and not for each crop type and soil type. Our results also imply that the negative precipitation anomalies during JJAS season will create a negative soil moisture anomaly, which is not be suitable for Rabi crops.

\subsection{Seasonal rainy days}

Crops require certain minimum amount of water supply continuously during their life period. Frequent occurrence of rainy days with low/moderate intensity of rainfall is more favourable for the growth of foodgrains (Revadekar and Preethi

Daily Evolution of wet year composite anomalies
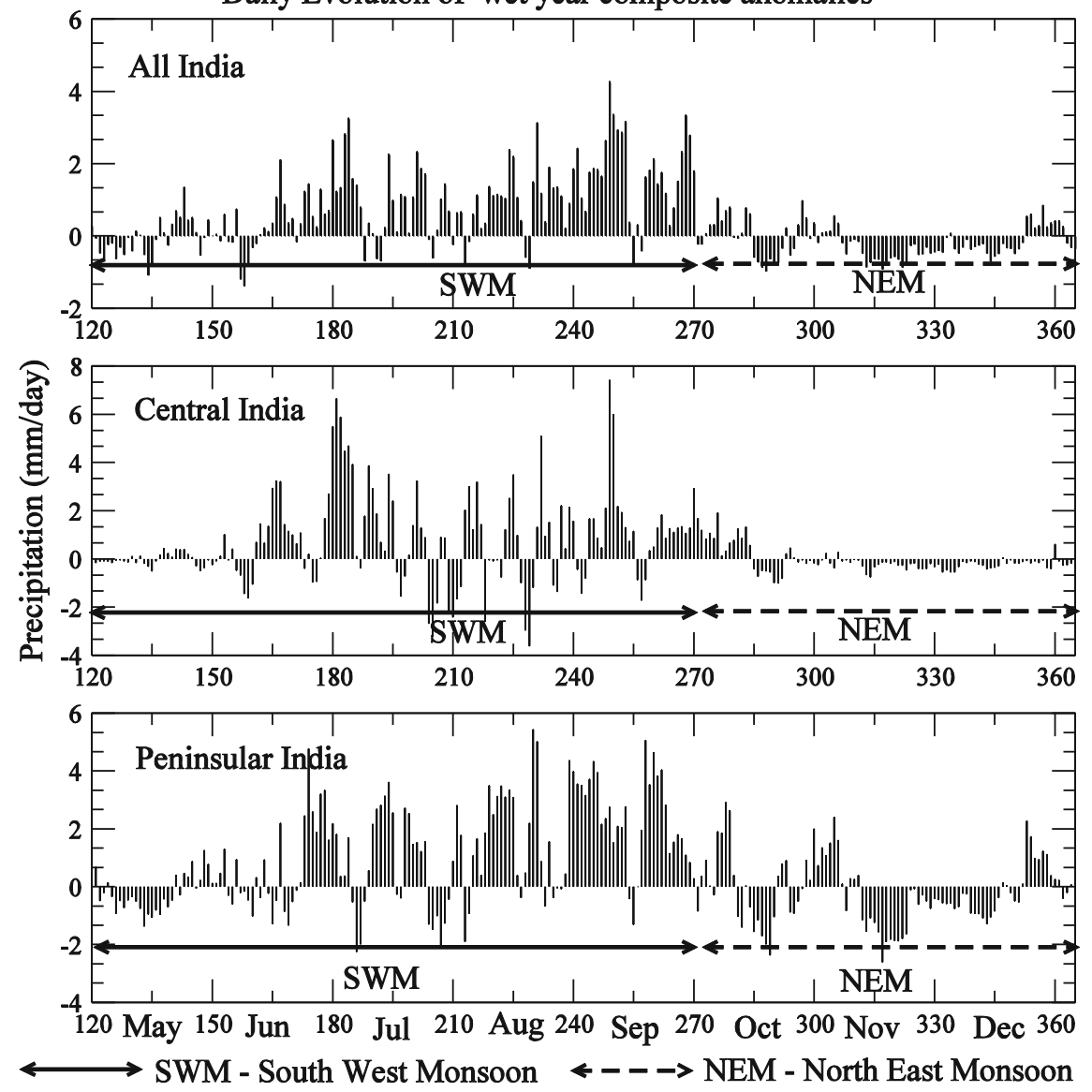

Figure 11. Daily evolution of wet year composites over different domains. 
2012). Therefore, variations of seasonal foodgrain yield with rainy days are also examined. A day is considered to be a rainy day when the rainfall of that day exceeds $2.5 \mathrm{~mm}$. The response of Kharif foodgrain to the variations in rainy days appears to be similar to that of seasonal precipitation. All the monsoon seasons having less number of rainy days are associated with negative anomalies in Kharif foodgrain yield and all the years with large number of rainy days are associated with positive anomalies in foodgrain yield.

The composite rainy days (number of rainy days) are prepared for JJAS and OND and the mean rainy days are shown in the top panel of figure 8 for wet years. The bottom panel shows the difference between all years rainy day count minus the wet year composite. Similarly, the composite rainy days (number of rainy days) are prepared for JJAS and OND and the mean rainy days are shown in the top panel of figure 9 for dry years. The bottom panel shows the difference between all years rainy day count minus the dry year composite.

We notice more number of rainy days during wet years (figure 8) and less number of rainy days during dry years (figure 9).

\subsection{Impact of daily rain anomalies on Indian foodgrain yields}

Apart from the seasonal mean rainfall, the daily variations in the rainfall amount also significantly affect the crop yield over India. The climatological daily rainfall for all-India, central India and peninsular India is shown in figure 10. From figure 10 , we can say that most significant precipitation is realized in the months of June to September (JJAS). The composite anomalies of daily precipitation for wet and dry years for the season JJAS is shown in figures 11 and 12, respectively. From figure 11, it is evident that all-India, central India and peninsular India show many clusters of positive daily anomalies during months June to September (JJAS), while we notice some small negative anomalies in the following OND season for wet years composite. Similarly, from figure 12, it is also evident that all-India, central India and peninsular India show many clusters of negative daily anomalies during months June to September (JJAS), while we do notice some small positive anomalies in the following OND season for dry years composite. But the anomalies are sufficiently large in the months of June to September (JJAS),

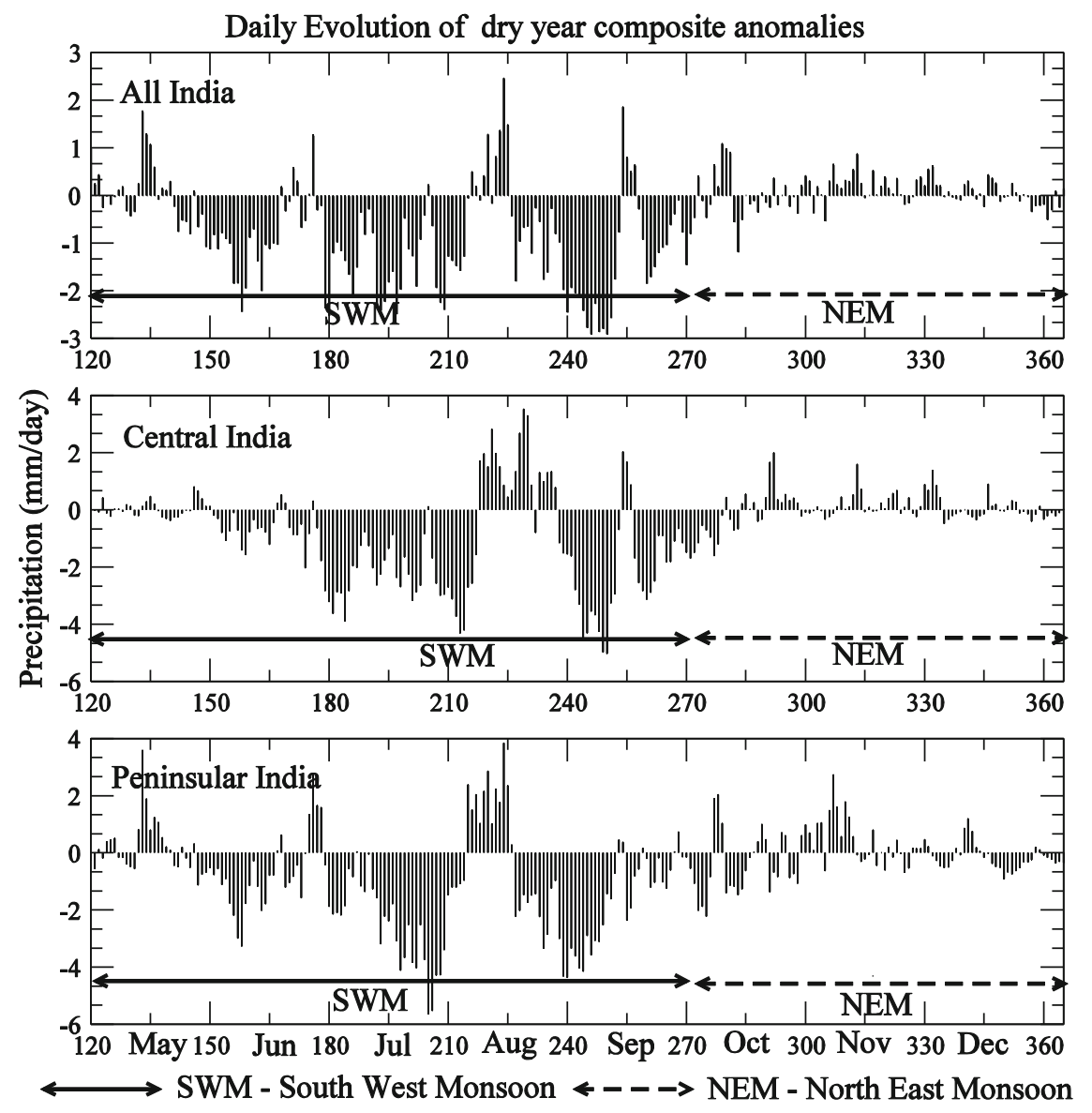

Figure 12. Daily evolution of dry year composites over different domains. 
whereas the anomalies during months of OND season are sufficiently lower, thereby making JJAS monsoon rainfall more important for both Kharif and Rabi crops, providing water and soil moisture for a better crop yield.

\subsection{Impact of prolonged break episodes}

The seasonal rainfall associated with the Asian summer monsoon (ASM) profoundly influences the agricultural and socio-economic sectors of south and southeast Asia, and the associated diabatic heating impacts circulation throughout the tropics and extratropics (Yasunari and Seki 1992; Hoskins and Rodwell 1995; Webster et al. 1998). Within the season (June-September (JJAS)) rainfall fluctuates between active (abundant) and break (scanty) spells. While breaks are inherent to monsoons, prolonged dryness or extended breaks (lasting 7 days or more) during the peak rainy season (JulyAugust) often result in droughts (Ramamurthy 1969).

Monsoon active/break spells arise from a superposition of multiple time-scale variations (synoptic (6-9 days), quasi-biweekly (10-20 days), and submonthly (30-50 days)), whose imprints are detectable in various atmospheric and oceanic parameters (Krishnamurti and Bhalme 1976; Yasunari
1979; Sikka and Gadgil 1980; Bhat 2006; Fujinami and Yasunari 2009; Rajeevan et al. 2010). Observations suggest that active periods are generally associated with decreased (increased) surface pressure along the monsoon trough anchoring stronger (weaker) moisture-laden low-level cross equatorial flow from the southern Indian Ocean, resulting in increased (decreased) cyclonic vorticity over the monsoon region. During typical break conditions the trough moves to the foothills of the Himalayas and dry conditions prevail over central and northwest India (Ramamurthy 1969). During extended breaks these features persist for a prolonged period.

Having recognized the consequences of breaks, several studies have attempted to elucidate relevant processes that initiate them. Space-time evolution of break composites constructed from either rainfall or outgoing longwave radiation (OLR) suggests dominance of the 30-50-day intraseasonal variability (Singh et al. 1992; Annamalai and Slingo 2001); specifically, during boreal summer convective anomalies associated with the equatorial eastward propagating Madden-Julian oscillation (MJO) interact with the monsoon and display northward propagation over south Asian longitudes and north-northwest migration over the tropical west Pacific (TWP) (Wang and Rui 1990; Annamalai and Slingo 2001). During its inactive
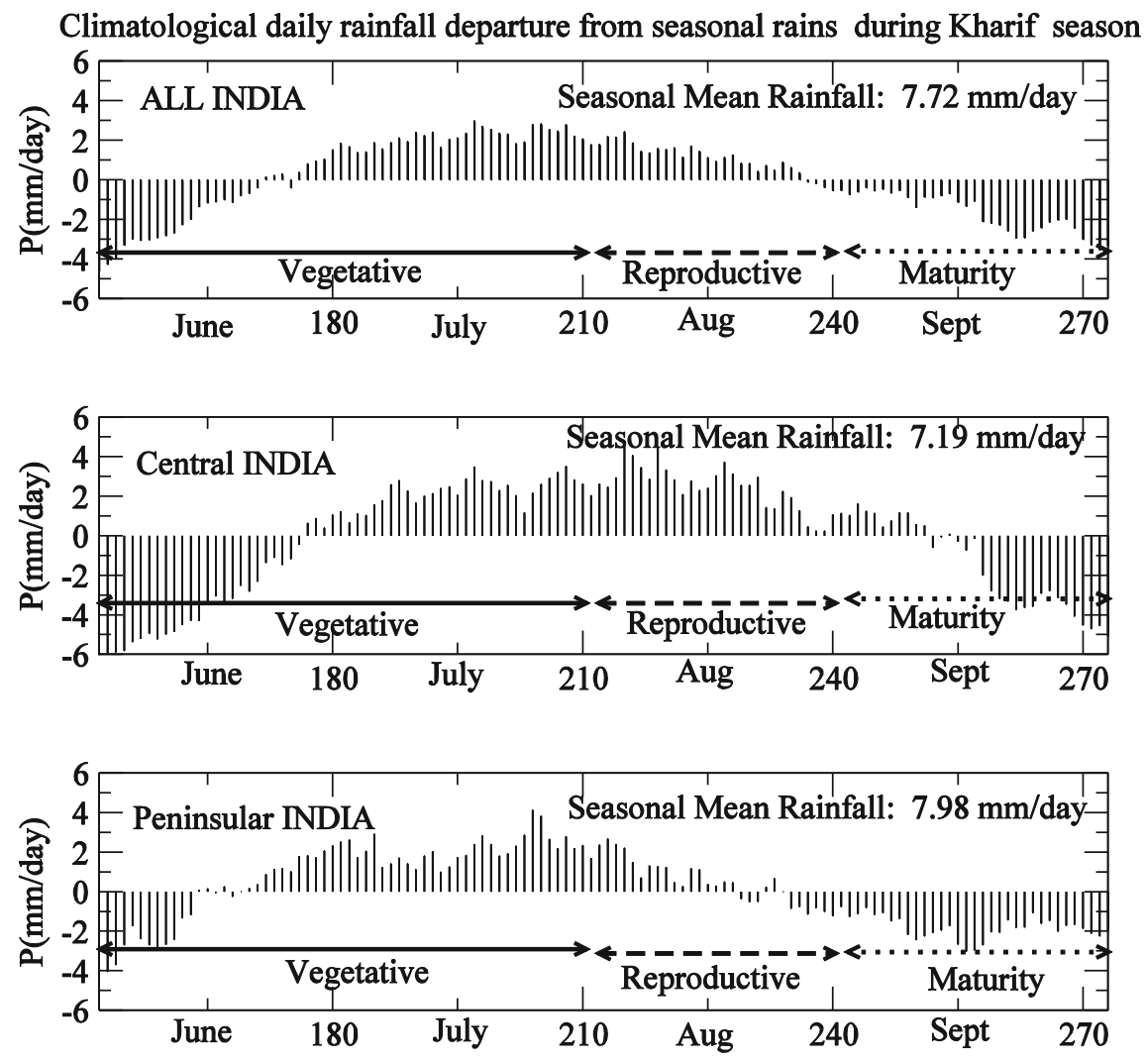

Figure 13. Climatological evolution of daily rainfall anomalies averaged over the all India, central and peninsular India during JJAS season (typical for a Kharif season). 
phase, dry convective anomalies, on reaching the Bay of Bengal, force Rossby waves that propagate westward and initiate breaks over central India (Krishnan et al. 2000).

Apart from the daily mean rainfall variations, the long breaks also significantly affect the crop yield over India. The prolonged breaks (or the long breaks or the extended breaks) tend to occur during weak monsoon years (Prasanna and Annamalai 2012).

As we can notice from figure 12 (the dry years composite), negative anomalies persisting for longer than a week ( $>7$ days) during SW monsoon season, a typical break monsoon signal over both central and peninsular India reinforcing the break condition in the all-India anomalies.

Prolonged breaks ( $>7$ days) causing droughtlike situations over India within a monsoon season, have paramount importance for agricultural impacts (Ramamurthy 1969; Raghavan 1973); extended breaks are interplay of intraseasonal oscillations and the effect of boundary forcing (Krishnan et al. 2000; Prasanna and Annamalai 2012).

The importance of rain spell during vegetative, reproductive, and maturity stages of crops are shown for JJAS and OND seasons in figures 13 and 14, respectively, considering a crop sown during early June (October) and harvested during late September (December) having to undergo a pattern of rainfall based on daily climatological anomalies calculated from the climatological seasonal mean. The patterns for JJAS (figure 13) and OND (figure 14) in a climatological sense clearly show that more precipitation is required during the later periods of vegetative stage and early periods of reproductive stage. Heavy precipitation during early vegetative stage and heavy precipitation during maturity stage may be detrimental to crop yield. This illustration does not represent a particular crop or a growing season, but provides a picture of rainfall pattern within a season in a climatological sense.

\subsection{Monsoon rainfall variability as a foodgrain yield indicator}

Large-scale droughts and floods in summer monsoon rainfall have a major impact on foodgrain production. From the analysis, it can be noted that the years with higher summer monsoon rainfall result in higher crop productivity and the years with lower summer monsoon rainfall result in lower crop productivity (tables 1 and 2). The tables clearly show the importance of JJAS precipitation
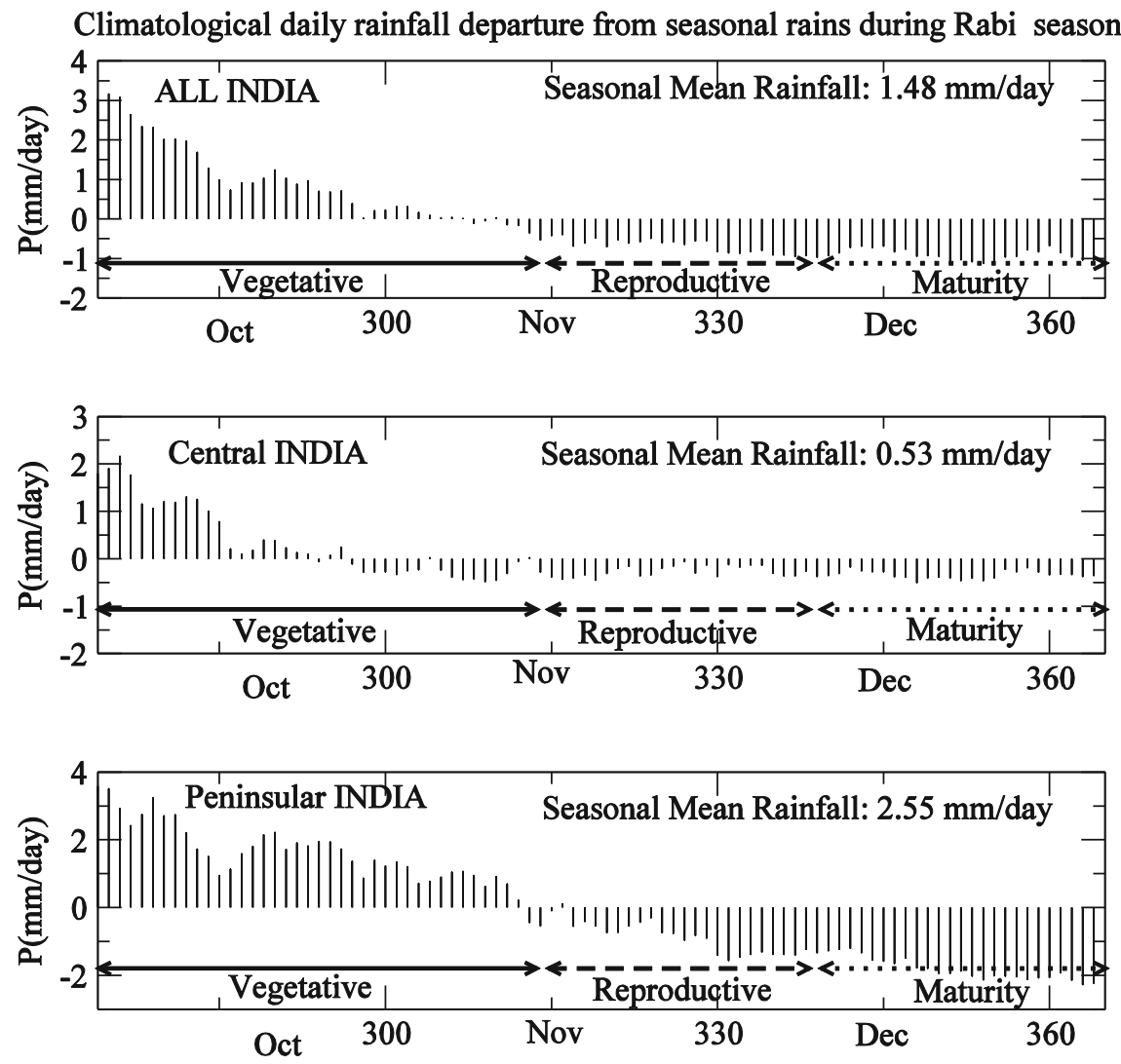

Figure 14. Climatological evolution of daily rainfall anomalies averaged over the all India, central and peninsular India during OND season (typical for a Rabi season). 
Table 1. WET year crop-climate relationship, where * indicates the strong relevance of summer monsoon precipitation during Rabi season irrespective of OND monsoon rainfall anomaly.

\begin{tabular}{ccccc}
\hline & $\begin{array}{c}\text { Standardised } \\
\text { RF anomaly } \\
\text { YJAS) }\end{array}$ & $\begin{array}{c}\text { Crop productivity } \\
\text { index in } \\
\text { Kharif season }\end{array}$ & $\begin{array}{c}\text { Corresponding crop } \\
\text { productivity index } \\
\text { in Rabi season }\end{array}$ & $\begin{array}{c}\text { Corresponding } \\
\text { standardised } \\
\text { anomaly (OND) }\end{array}$ \\
\hline 1970 & 1.33 & 94.91 & 56.87 & -0.94 \\
1975 & 1.61 & 35.68 & -15.41 & 0.92 \\
1983 & 1.52 & 28.71 & -4.64 & 0.18 \\
1988 & 1.59 & 23.49 & $102.09^{*}$ & -1.42 \\
1994 & 1.49 & 68.01 & $118.16^{*}$ & 0.11 \\
2007 & 1.27 & 78.82 & -29.34 & -1.26 \\
\hline
\end{tabular}

Table 2. Dry year crop-climate relationship, where * indicates the strong relevance of summer monsoon precipitation during Rabi season irrespective of OND monsoon rainfall anomaly.

\begin{tabular}{lcccc}
\hline & $\begin{array}{c}\text { Standardised } \\
\text { RF anomaly } \\
\text { YJJAS) }\end{array}$ & $\begin{array}{c}\text { Crop productivity } \\
\text { index in Kharif } \\
\text { season }\end{array}$ & $\begin{array}{c}\text { Corresponding crop } \\
\text { productivity index } \\
\text { in Rabi season }\end{array}$ & $\begin{array}{c}\text { Corresponding } \\
\text { standardised RF } \\
\text { anomaly (OND) }\end{array}$ \\
\hline 1972 & -2.14 & -37.58 & -17.44 & -0.46 \\
1974 & -0.99 & -90.07 & -41.75 & -0.02 \\
1979 & -1.47 & -159.30 & $-159.02 *$ & 0.81 \\
1982 & -1.14 & -125.04 & -15.98 & -0.65 \\
1986 & -1.05 & -113.02 & -8.95 & 0.80 \\
1987 & -1.60 & -124.27 & -21.26 & 1.43 \\
2002 & -2.03 & -181.96 & $-92.07 *$ & -1.03 \\
2004 & -1.03 & -68.45 & $-92.38^{*}$ & -0.52 \\
\hline
\end{tabular}

over OND precipitation on the Kharif and Rabi crop yield. A few years Rabi crop yield anomalies follow JJAS precipitation anomalies irrespective of the precipitation anomalies during OND season.

\section{Conclusions}

All-India crop yield index shows a strong relationship with all-India summer monsoon rainfall. Crops grown in both the monsoon (Kharif) and the postmonsoon (Rabi) seasons respond significantly to the summer monsoon (JJAS).

Kharif (summer) is the main crop growing season over India. Foodgrain yield during Kharif season is directly affected by day-to-day variations of summer monsoon (June through September) precipitation. An increase (decrease) in foodgrain yield is generally associated with an increase (decrease) in rainfall. A drought in summer monsoon generally leads to a large reduction in foodgrain yield. However, the occurrence of heavy rainfall activity can also have an adverse effect on the crop growth. The Indian summer monsoon has large intraseasonal variability of rainfall and hence the day-to-day variation of rainfall can have significant impact on the Kharif foodgrain yield of the country. The present study has clearly brought out the role of day-today variation in Indian summer monsoon precipitation on Kharif foodgrain yield and also Rabi foodgrain yield over India for the period 19662010.

All lower (higher) values of seasonal precipitation and rainy days are mostly associated with negative (positive) anomalies in both Kharif foodgrain yield and Rabi foodgrain yield. Similar to seasonal precipitation and rainy days, the intensity of rainy spell of one day to several days of negative (positive) rainfall are associated with negative (positive) anomalies of Kharif and Rabi foodgrain yield for lower (higher) ranges of the indices. Duration of wet or dry spells during the monsoon season plays a critical role in determining the deficient/drought condition, which may lead to low yields; flood conditions may also lead to low yields. Therefore prolonged active/break episodes can potentially change water availability and soil moisture availability with in a season to impact crop yield. 


\section{Acknowledgement}

Author wishes to express his sincere thanks to Dr Chin-Seung Chung, Director APEC Climate Center for his constant encouragement and necessary facilities to carry out this work.

\section{References}

Annamalai H and Slingo J M 2001 Active/break cycles: Diagnosis of the intraseasonal variability of the Asian summer monsoon; Clim. Dyn. 18 85-102.

Abrol Y P and Gadgil S 1999 Rice - in a variable climate; APC Publications Pvt Ltd, New Delhi, 243p.

Bhat G S 2006 The Indian drought of 2002: A subseasonal phenomenon? Quart. J. Roy. Meteor. Soc. 132 25832602.

Box G E P and Jenkins G M 1976 Time Series Analysis: Forecasting and Control, 2nd edn (San Francisco: Holden Day).

DES 2010 Agricultural statistics at a glance; Directorate of Economics and Statistics, Department of Agriculture and Cooperation, Ministry of Agriculture, Govt. of India, New Delhi.

Dhar O N and Rakhecha P R 1983 Forecasting northeast monsoon rainfall over Tamil Nadu, India; Mon. Wea. Rev. 111 109-112.

Fan Y and van den Dool H 2004 Climate Prediction Center global monthly soil moisture data set at $0.5^{\circ}$ resolution for 1948 to present; J. Geophys. Res. 109 D10102, doi: 10.1029/2003JD004345.

Fujinami H and Yasunari T 2009 The effects of midlatitude waves over and around the Tibetan Plateau on submonthly variability of the East Asian summer monsoon; Mon. Wea. Rev. 137 2286-2304.

Gadgil S 1996 Climate change and agiculture - an Indian perspective; In: Climate Variability and Agriculture (eds) Abrol Y R, Gadgil S and Pant G B (New Delhi, India: Narosa), pp. 1-18.

Gadgil S, Abrol Y P and Seshagiri Rao P R 1999 On growth and fluctuation of Indian foodgrain production; Curr. Sci. 76 548-556.

Gadgil S and Rupa Kumar K 2006 The Asian monsoon agriculture and economy; The Asian Monsoon (ed.) Wang B, Springer Praxis, 5 651-683.

Hoskins B J and Rodwell M J 1995 A model of the Asian summer monsoon. Part I: The global scale; J. Atmos. Sci. 52 1329-1340.

Krishnamurti T N and Bhalme H N 1976 Oscillations of a monsoon system. Part I: Observational aspects; J. Atmos. Sci. 33 1937-1954.

Krishnan R, Zhang C and Sugi M 2000 Dynamics of breaks in the Indian summer monsoon; J. Atmos. Sci. $\mathbf{5 7}$ 1354-1372.

Krishna Kumar K, Rupa Kumar K, Ashrit R, Deshpande N R and Hansen J W 2004 Climate impacts on Indian agriculture; Int. J. Climatol. 24 1375-1393.

Krishnamurthy V and Shukla J 2008 Seasonal persistence and propagation of intraseasonal patterns over the Indian summer monsoon region; Clim. Dyn. 30 353-369.

Kumar P, Rupa Kumar K, Rajeevan M and Sahai A K 2007 On the recent strengthening of the relationship between ENSO and northeast monsoon rainfall over south Asia; Clim. Dyn. 28 649-660.
Kumar K S and Parikh J 1998 Climate change impacts on Indian agriculture: The Ricardian Approach; In: Measuring the Impact of Climate Change on Indian Agriculture (eds) Dinar A, Mendelsohn R, Evenson R, Parikh J, Sanghi A, Kumar K, McKinsey J and Lonergan S, Technical Paper 402, World Bank, Washington DC.

Pant G B and Rupakumar K 1997 Climates of South Asia; John Wiley \& Sons, Chichester, 320p.

Parthasarathy B and Pant G B 1985 Seasonal relationship between Indian summer monsoon rainfall and southern oscillation; J. Climate 5 369-378.

Parthasarathy B, Munot A A and Kothawale D R 1988 Regression model for estimation of foodgrain production from summer monsoon rainfall; Agric. Forest Meteorol. 42 167-182.

Parthasarathy B, Rupa Kumar K and Munot A A 1992 Forecast of rainy season foodgrain production based on monsoon rainfall; Indian J. Agric. Sci. 62 1-8.

Parthasarathy B, Munot A A and Kothawale D R 1995 All India monthly and seasonal rainfall series: 1871-1993; Theor. Appl. Climatol. 49 217-224.

Prasanna V and Yasunari T 2008 Interannual variability of atmospheric water balance over south peninsular India and Sri Lanka during north east monsoon season; Int. J. Climatol. 28 1997-2009.

Prasanna V and Yasunari T 2009 Time-space characteristics of seasonal and interannual variations of atmospheric water balance over south Asia; J. Meteorol. Soc. Japan 87(2) 263-287.

Prasanna V and Annamalai H 2012 Moist dynamics of extended monsoon breaks over south Asia; J. Climate 25 3810-3831.

Preethi B and Revadekar J V 2012 Kharif food grain yield and daily summer monsoon precipitation over India; Int. J. Climatol., doi: 10.1002/joc.3565.

Raghavan K 1973 Break monsoon over India; Mon. Wea. Rev. $10133-43$.

Rajeevan M, Bhate J, Kale J D and Lal B 2005 Development of a high resolution daily gridded rainfall data for the Indian region; IMD Met Monograph No: Climatol. 22 27.

Rajeevan M, Bhate J, Kale J D and Lal B 2006 High resolution daily gridded rainfall data for the Indian region: Analysis of break and active monsoon spells; Curr. Sci. $91296-306$.

Rajeevan M, Gadgil S and Bhate J 2010 Active and break spells of the Indian summer monsoon; J. Earth Syst. Sci. $119229-247$.

Ramamurthy R 1969 Monsoons of India: Some aspects of the break in the southwest monsoon during July-August; India Meteorol. Department Forecasting Manual Part IV $\mathbf{1 8 . 3} 13$

Revadekar J V and Preethi B 2012 Statistical analysis of the relationship between summer monsoon precipitation extremes and food grain yield over India; Int. J. Climatol., doi: 10.1002/joc.2282.

Santosh U, Guggari A K, Babalad H B, Sarwad I M, Venkatesh H and Patil A B 2011 Yield, economics and available soil moisture as influenced by soil types in different Rabi crops under rainfed conditions; Karnataka J. Agric. Sci. 24(3) 286-288.

Selvaraju R 2003 Impact of El Nino-southern oscillation on Indian foodgrain production; Int. J. Climatol. 23 187-206.

Sikka D R and Gadgil S 1980 On maximum cloud zone and ITCZ over Indian longitude during the southwest monsoon; Mon. Wea. Rev. 108 1840-1853. 
Singh S V, Kripalani R H and Sikka 1992 Interannual variability of the Madden-Julian oscillations in Indian summer monsoon rainfall; J. Climate 5 973-978.

Swaminathan M S 1987 Abnormal monsoons and economic consequences: The Indian experiment; In: Monsoons (eds) Fein J S and Stephens P L, Wiley and Sons, New York, pp. 121-134.

Wang B and Rui H 1990 Synoptic climatology of transient tropical intraseasonal convective anomalies: 1975-1985; Meteor. Atmos. Phys. 44 43-61.
Webster P J, Magana V O, Palmer T N, Shukla J, Thomas R A, Yanai M and Yasunari T 1998 Monsoons: Processes, predictability and the prospects of prediction; J. Geophys. Res. 103 14,451-14,510.

Yasunari T 1979 Cloudiness fluctuations associated with the northern hemisphere summer monsoon; J. Meteor. Soc. Japan 57 227-242.

Yasunari T and Seki Y 1992 Role of the Asian monsoon on the interannual variability of the global climate system; J. Meteor. Soc. Japan $\mathbf{7 0} 177-189$.

MS received 29 August 2013; revised 20 December 2013; accepted 10 February 2014 